\title{
LAKES IN GYPSUM KARST: \\ SOME EXAMPLES IN ALPINE AND MEDITERRANEAN \\ COUNTRIES
}

\author{
JEZERA V KRASU V SADRI: \\ NEKAJ PRIMEROV IZ ALPSKIH IN SREDOZEMSKIH DEŽEL
}

Jean NICOD ${ }^{1}$

\begin{abstract}
:
UDC 556.55(467.1) 551.444(467.1)

Jean NICOD: Lakes in Gypsum Karst: some examples in Alpine and Mediterranean countries.

Numerous lakes of varying types have been studied in these areas. Their origin proceeds from the geomorphological processes in the gypsum karst: land subsidence or collapses in relation with the active dissolution of the gypsum and other evaporites, particularly in depth, at the groundwater level.

Most are small lakes, often ephemeral ponds in the alpine gypsum karsts, or flooded sinkholes in alluvial plains, in keeping with the fluctuations of the water-table. However, in the Mediterranean lands and Central Europa, some lacustrine basins are more important expanse; they arise from a complex evolution, and put various environmental problems. So are particularly studied the case of the lake of Besse in Provence, and in comparison the problems of the lakes of Pergusa (Sicily) and Banyoles (Catalonia).
\end{abstract}

Key words: Evaporite karst, gypsum, lake, Alps, Mediterranean.

\begin{abstract}
Izvleček
UDK 556.55(467.1) 551.444(467.1)

Jean Nicod: Jezera $v$ krasu $v$ sadri: nekaj primerov iz alpskih in sredozemskih dežel

$\mathrm{V}$ teh predelih so bila preučevana številna jezera različnih tipov. Nastala so zaradi geomorfoloških procesov v krasu v sadri, kot so: ugrezi ali udori $\mathrm{v}$ zvezi $\mathrm{z}$ raztapljanjem sadre in ostalih evaporitov, predvsem $\mathrm{v}$ globinah, $\mathrm{v}$ višini talne vode. Večina teh jezer je majhnih, često so to občasna jezerca $\mathrm{v}$ krasu $\mathrm{v}$ sadri $\mathrm{v}$ Alpah, ali pa zalite vrtače v aluvialnih ravninah, ki odražajo nihanje gladine talne vode. V sredozemskih deželah in v Srednji Evropi pa so nekatera povodja teh jezer precej večja; njihovemu nastanku so botrovali različni dejavniki in v zvezi $\mathrm{z}$ njimi se pojavljajo različne ekološke težave. Kot primer je posebej predstavljeno jezero Besse v Provansi, za primerjavo pa še jezeri Pergusa (Sicilija) in Banyoles (Katalonija).
\end{abstract}

Ključne besede: evaporitni kras, sadra, jezero, Alpe, Sredozemlje.

\section{INTRODUCTION}

Although the lakes in gypsum or evaporites karst are not generally studied, but only by local or punctual works, their processes of formation and evolution are very interesting. They present specific characteristics comparatively to karstic lakes in limestones and dolomites:

- the quick genesis of their basin, frequently by breakdown, collapse or suffosion processes consecutive to the accelerated solution of the gypsum or andhydrite (and more in the halite lens!) (NICOD 1993, KLIMCHOUK 1996, 2002);
- the possible extension by solution and land subsidence, recess of the borders by solution and collapse, or coalescence of contiguous sinkholes;

- their variable water level, depended not only on the hydrologic conditions (change of the groundwater level, input-output balance), but also on the subsidence or collapse of their basin bottom;

- the silting by the clay derived from the weathering of the argilaceous beds joined up the gypsum or other evaporites:

${ }^{1}$ Emeritus professor, Florida 1, 35 Av. 24 Avril 1915, F 13012 MARSEILLE.

Received / Prejeto: 13.03.2006 
- the high mineralization, poor ichtyologic fauna, locally anoxic water and possible sulfhydric gas irruption in relation with the bacterial action on dissolved sulphates.

As do all the phenomenons in gypsum karsts when they occur in the urban and suburban areas, the gypsum lakes give main impact problems: the changes of lake level and possible extension, or on the contrary silting and trend to marsh.

\section{FORMS AND ORIGINS OF THE GYPSUM LAKES.}

\section{THE LAKES IN SMALL KARSTIC DEPRESSIONS} Most small lakes are located in karstic forms, funnel or sinkholes, produced by breakdown or collapse processes in relationship with active solution (fig. 1). In the alpine gypsum karst, as that of Col du Joly, Beaufortin (Savoie, France), a field of many funnels extend upon the outcrop of gypsum layers, in the mountain pasture, near 1900$2000 \mathrm{~m}$ (NICOD 1988). When the bottom of these depressions are blocked by residual clay or issued from morainic deposits, the lakes can be formed, but fast changed into marshs and bogs. (Photo 1)

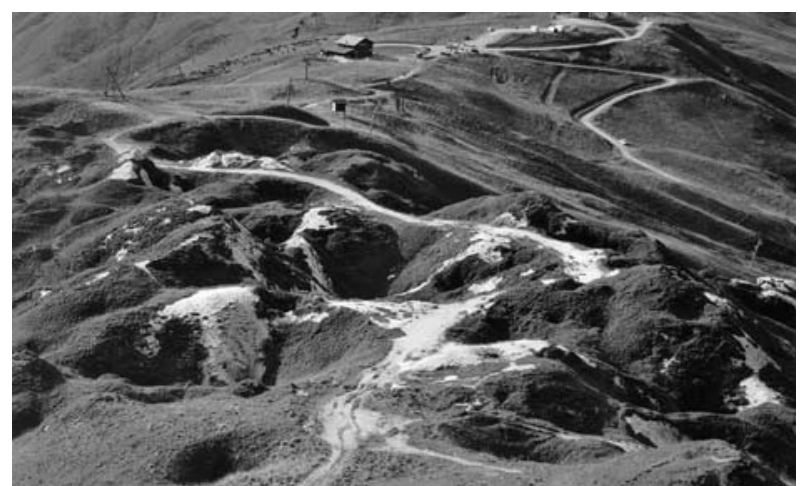

Photo 1: Small transient ponds in gypsum funnels, in the alpine pasture near Col du Joly (1989 m), in the northern Beaufortin (Savoie).

On the contrary, the gypsum lakes in the lower altitudes, in plateau or plain, are connected with the aquifer, either in alluvial deposits, example of the lagunas (dolinelakes) in the Ebro terraces (W Zaragoza SORIANO, 1991), or with a multilayered aquifer, as in gypsum karst of the triassic plateaus of the inner Provence (example of the Louciens, La Roquebrussane, Var Department). The level of those lakes depends to the watertable, as the case they can be perennial or temporary; in the occurence of speed groundwater lowering, the bottom of the basin may be changed by subsidence or collapse processes. In the example of the Grand Loucien, the excessive level variation cause sometimes rockslides in limestone borders: so this crater-like landform tend to extend. (Photo 2)

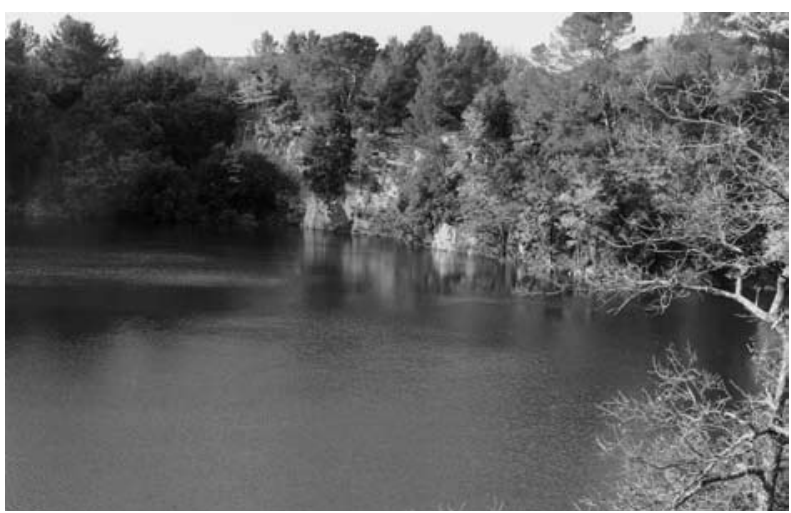

Photo 2: The "Grand Loucien » near La Roquebrussanne (Central Var Department). Collapse basin in middle Trias limestones, variable level in connection to the groundwater.

\section{THE POSSIBLE COMBINATION OF PROCESSES.}

Some lacustrine basins proceed from a combination of two or several development processes. So in high altitude (near $2300 \mathrm{~m}$ ) and alpine landscape, the lake of the Combe de la Nova in Beaufortin (Savoie), a submerged uvala in triassic gypsum band between shales, flows out in a sink-cave, active rockfall site (fig. 1, II). In the case of the lake of Mont-Cenis pass (1970 m, in Savoie, at the french-italian border) the glacial origin is clear, but a part of this basin is in a triassic gypsum band, where numerous funnels and sinkhole are opened; this structural arrangement has given a problem of losses, because of the raised level since the fitting out of the basin as reservoir for the hydroelectric power-plant (NICOD 1993). In the case of the Bonne Cougne pond, near Flassans in central Var Departement, it is spring-lake located in small polje in dolomites of middle Trias, now drained; its origin is in keeping with the dissolution of the underlying evaporitic lens, as in the lake of Besse (infra). In the "Causses " of the Middle Atlas (Morocco), several lacustrine basins in liassic limestones and dolomites proceed from the same processes: disssolution of underlying triassic gypsum lens, some in diapiric structures, and subsidence of the layers on top. Some are seasonal lakes (daias), as in the Ouiouane polje, and turn into salt crust in summer (MARTIN 1981). (Photo 3) 


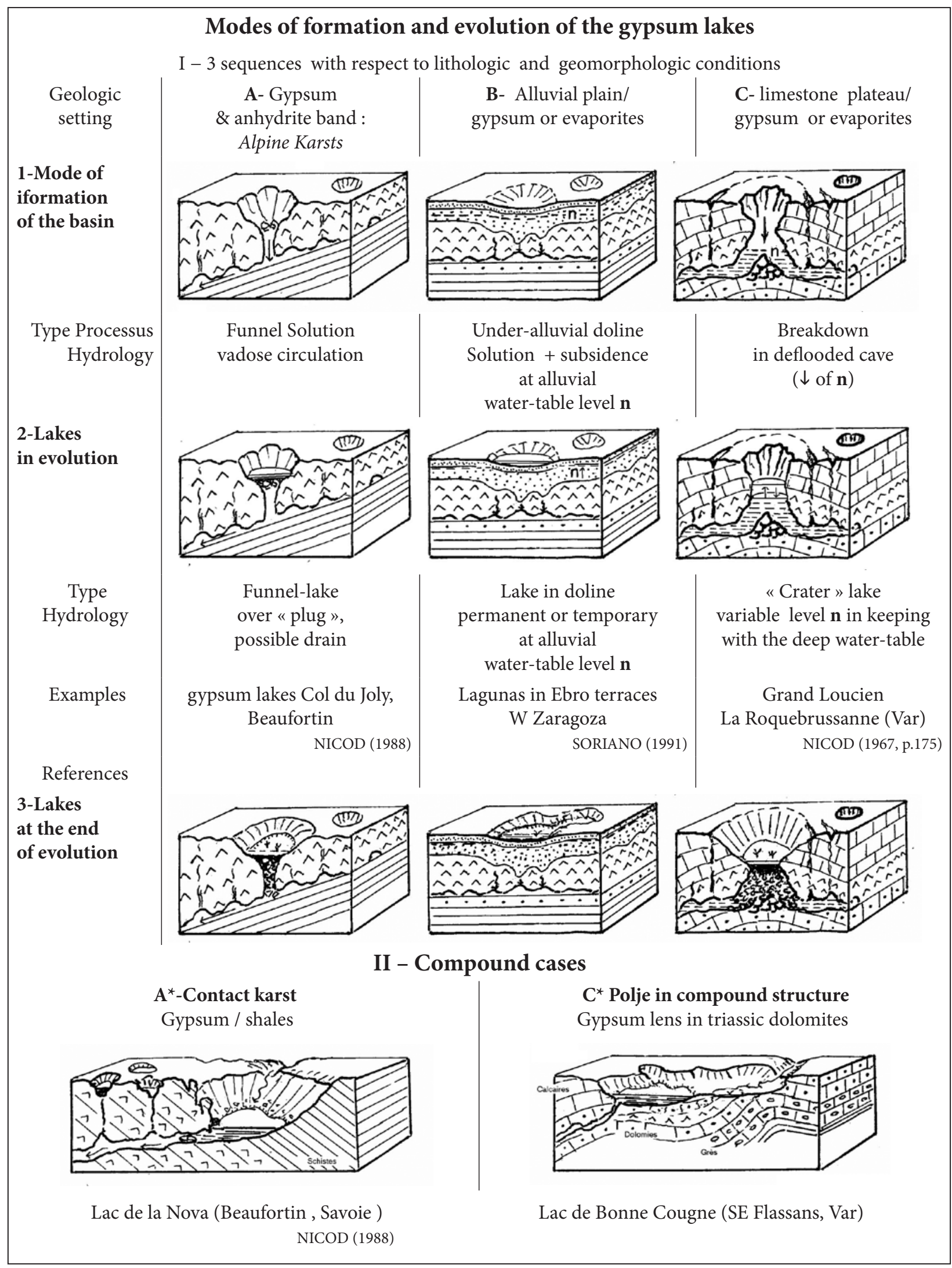

Fig. 1: Some basic types of formation and evolution of the lakes in gypsum karst. 


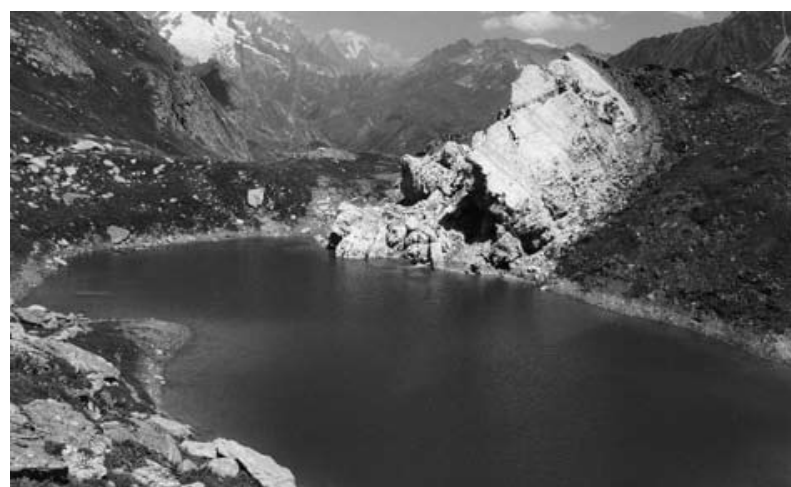

Photo 3: The lake of the Combe de la Nova (2300 m, Beaufortin Savoie), submerged uvala in triassic gypsum band between shales. Loss in the gypsum rockfall (1994).

\section{THE CASE OF AGUELMANE AZIGZA: RAIN-GAUGE LAKE !}

Aguelmane Azigza (the Green Lake in Berber language) is situated in the southern part of the Causses of the Middle Atlas (Morocco). This main lake of the Causse of Ajdir, without outlet, gives spectacular inter-annual water-level changes: it is a record of the dry and humid periods at the regional scale. It is extended in the eastern end of an important polje, old landform expanded in the liassic dolomites, near $1490 \mathrm{~m}$ high, characterised by cupola hums and flat ground covered by residual deposits, dolomitic sands and terra rossa (MARTIN, 1981). The basin of the lake is a subsidence depression, following the fault system, in relationship with the dissolution of the evaporites in the underlying triassic formation. Active collapses and block-fallings in dominant scarps of liassic dolomitic limestones prove the permanence of this process. This play of dissolution at groundwater level, in the area of Causse of Ajdir is correlated with some sulphated and salt springs, north of this Causse, in the Oum-erRbia canyon (EL KHALKI \& AKDIM 2001). (Photo 4 and Photo 5)

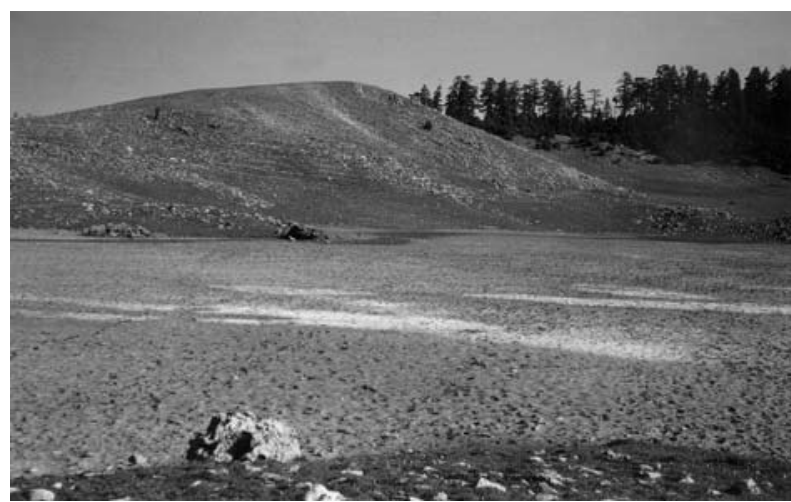

Photo 4: Small lake (daia), doline in diapiric structure (Causse d'Ajdir, Middle Atlas). Dry in summer, with salt crust (Photo Y. EL Khalki).

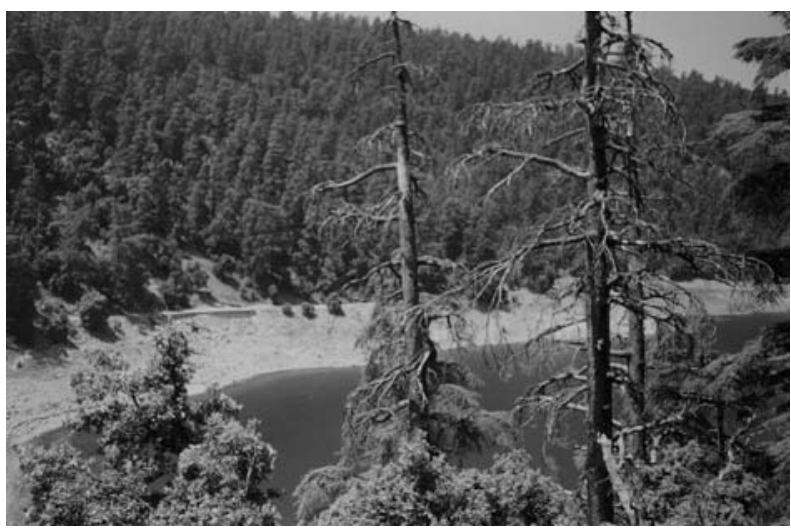

Photo 5: The lake Azigza, in the Causse d'Ajdir (Middle Atlas). Low level showed by the white scree, below the trail and cedar forest.

This part of the Middle-Atlas Causses is relatively good sprinkled and snow-covered in winter; the cedar forest subsists on the base of the scarps; but the interannual change of the rainfall and snow amount is very important. The rainfall and snow-melting in the polje supply the Aguelmane, however with high evaporation $(\sim 600 \mathrm{~mm} / \mathrm{y})$; but the lake-level is in connection with the aquifer in the dolomitic layers. Also this level can changed between $1490 \mathrm{~m}$ (in 1960) and $1471 \mathrm{~m}$ (1984), and even $1470 \mathrm{~m}$ in 1990. In high level, the lake may overflow in the polje; in lowest level, it covers only $37 \mathrm{ha}$, with $38 \mathrm{~m}$ of maximum deep.

The low level is in relationship with dry sequences, but a phase-lag of one or two years between the weak precipitations and the lowest water-level has be recognised (FLOWER \& FOSTER, 1992): in my opinion that is caused by the slow response of the aquifer play in the liassic dolomites.

\section{SOME MAIN LAKES.}

In Central-Europe and Mediterranean countries, some largest lakes give variable forms, in relationship with diverse structures and hydrogeological settings, multiple evolution processes and various water supply. The table 1 shows the most important and knownest lakes, as representative examples of environmental problems. 
Tab. 1: Main gypsum lakes in Central-Europe and Mediterranean countries, sorted according to their extension.

\begin{tabular}{|c|c|c|c|c|}
\hline $\begin{array}{l}\text { Lake } \\
\quad \text { Region, Land }\end{array}$ & $\begin{array}{l}\text { Surface } \\
\text { Altitude }\end{array}$ & $\begin{array}{l}\text { Depth. } \\
\text { average } \\
\max \end{array}$ & $\begin{array}{c}\text { Type } \\
\text { Genesis } \\
\text { Lithology }\end{array}$ & $\begin{array}{c}\text { Working } \\
\text { Hydrosystem } \\
\text { Peculiarities }\end{array}$ \\
\hline $\begin{array}{l}\text { L. Invârtita (Nucşoara) } \\
\text { Argeş Distr., Transilvania, Rom. } \\
\text { BULGAREANU } 1997\end{array}$ & $\begin{array}{l}0.02 \mathrm{~km}^{2} \\
877 \mathrm{~m}\end{array}$ & $\sim 5 \mathrm{~m}$ & $\begin{array}{l}\text { Extended sinkhole from } \\
\text { a ponor in the end of } 19^{\text {th }} \\
\text { c. gypsum, aquitanian } \\
\text { sandstone }\end{array}$ & $\begin{array}{l}\text { Supplied by groundwater } \\
\text { anoxic basin } \\
\text { emit } \mathrm{H}_{2} \mathrm{~S}\end{array}$ \\
\hline $\begin{array}{l}\text { L de Besse (Besse-sur-Issole) } \\
\text { Var Dept., E Provence, F. } \\
\text { NICOD 1991/99 }\end{array}$ & $\begin{array}{l}0.04 \mathrm{~km}^{2} \\
245 \mathrm{~m}\end{array}$ & $\begin{array}{l}3-4 \mathrm{~m} \\
9 \mathrm{~m}\end{array}$ & $\begin{array}{l}\text { Collapse doline } \\
\text { Middle-Trias limestones } \\
\text {-id.- gypsum }\end{array}$ & $\begin{array}{l}\text { In connection with } \\
\text { aquifer + made-man } \\
\text { supply by Issole partial } \\
\text { drain-off in } 1989\end{array}$ \\
\hline $\begin{array}{l}\text { Nixsee (Nixei) } \\
\text { Harzvorland (E Göttingen), D. } \\
\text { PRIESNITZ, } 1969\end{array}$ & $\begin{array}{l}0.02-0.08 \\
\text { in flood } \rightarrow \\
250 \mathrm{~m}\end{array}$ & $6 \mathrm{~m}$ & $\begin{array}{l}\text { Little polje } \\
\text { dolomites } \\
\text { gypsum of Zechstein }\end{array}$ & $\begin{array}{l}\text { Flooded by spring } \\
\text { (Springwiese) } \\
\text { outflow } \rightarrow \text { ponor }\end{array}$ \\
\hline $\begin{array}{l}\text { Laguna Grande (Archidona) } \\
\text { Betic range, Andalucia, Spain } \\
\qquad \text { PULIDO-BOSCH, } 1989\end{array}$ & $0.06 \mathrm{~km}^{2}$ & & $\begin{array}{l}\text { Subsidence depression } \\
\text { gypsum \& halite of Trias }\end{array}$ & $\begin{array}{l}\text { In relation with aquifer } \\
\rightarrow \text { Fuente Camacho } \\
\text { Saline, dry in summer }\end{array}$ \\
\hline $\begin{array}{l}\text { Aguelmane Azigza } \\
\text { Causse of Ajdir, Middle-Atlas, M. } \\
\text { MARTIN } 1981\end{array}$ & $\begin{array}{l}0.34 \mathrm{~km}^{2} \\
1490 \grave{a} \\
1471 \mathrm{~m}\end{array}$ & $\begin{array}{l}33 \mathrm{~m} \\
\text { (en 1989) }\end{array}$ & $\begin{array}{l}\text { Collapse fault trough } \\
\text { near polje in dolomites } \\
\text { of Lias } \\
\text { Trias clay + evaporites }\end{array}$ & $\begin{array}{l}\text { Supplied by polje \& } \\
\text { aquifer very variable } \\
\text { water-level Rain-gauge } \\
\text { lake! }\end{array}$ \\
\hline $\begin{array}{l}\text { Lago di Pergusa (Enna) } \\
\text { Central Sicily, Italy } \\
\qquad \text { D'AMORE } 1983\end{array}$ & $\begin{array}{l}1.18 \mathrm{~km}^{2} \\
667 \mathrm{~m}\end{array}$ & $1,8 \mathrm{~m}$ & $\begin{array}{l}\text { Large doline } \\
\text { Pliocène marls } \\
\begin{array}{l}\text { Messinian gypsum }+ \\
\text { halite }\end{array}\end{array}$ & $\begin{array}{l}\text { Rain supply }+ \\
\text { groundwater without } \\
\text { outlet trend to silting }\end{array}$ \\
\hline $\begin{array}{l}\text { Estany de Banyoles (Bañolas) } \\
\text { Ampurdan, Catalonia, Spain } \\
\text { JULIA BRUGUES } 1980\end{array}$ & $\begin{array}{l}1.83 \mathrm{~km}^{2} \\
173 \mathrm{~m}\end{array}$ & $\begin{array}{l}10 \mathrm{~m} \text { au } \mathrm{N} \\
20 \mathrm{~m} \text { au } \mathrm{S} \\
130 \mathrm{~m} !\end{array}$ & $\begin{array}{l}\text { Coalescence of sinkholes } \\
+ \text { travertine dam } \\
\text { Eocene marls/gypsum }\end{array}$ & $\begin{array}{l}\text { Supply by aquifer Anoxic } \\
\text { bottom emit } \mathrm{H}_{2} \mathrm{~S}\end{array}$ \\
\hline $\begin{array}{l}\text { Demiryurt gölü (Todürge gölü) } \\
\text { Karst of Sivas, Anatolia, Turkey } \\
\text { ALAGÖZ, } 1967\end{array}$ & $\begin{array}{l}3.3 \mathrm{~km}^{2} \\
1295 \mathrm{~m}\end{array}$ & $\begin{array}{l}\sim 4 \mathrm{~m} \\
28 \mathrm{~m} \\
\text { (funnel) }\end{array}$ & $\begin{array}{l}\text { Submerged uvala } \\
\text { Miocene gypsum }\end{array}$ & $\begin{array}{l}\text { Supply by aquifer } \\
+ \text { affluent } \\
\text { Outflow } \rightarrow \text { Kizyl-Yrmak } \\
\text { summer reduction } \rightarrow \text { salt } \\
\text { crusts }\end{array}$ \\
\hline
\end{tabular}

\section{ENVIRONMENTAL PROBLEMS}

The leak of the Lac de Besse (Central Provence), a «bottomless lake»!

This widest lake (4 ha) in the triassic plateaus of the Var Department is located near the old little town of Besse-sur-Issole. Its basin is a karstic depression in anticlinal structure of the middle Trias limestones (Muschelkalk); below the factured limestones (that make up the spur and cliff at the NW), the «Anhydritgruppe» formation is constituted by dolomites, dolomitic marls and gypsum (fig. 2). Mainly, the confined aquifer in these triassic formations and the outflow to the Issole river main- tains the level of the lake, normanly nine metres deep; but in the dry years, the level can progressively subside, as in 1878; on account of this lowering, a small canal diverted from the Issole contributes to the supply of the basin. (Photo 6)

In december 1989, the level falls quickly, and the regional press print in enormous headlines: "Après le gouffre glouton, le lac qui fuit!», after the greedy pit, the leaky lake! A small cave opened on foot of the limestone cliff has absorbed in part the lake water (fig. 3), as previously in similar event in 1987 for one river near 


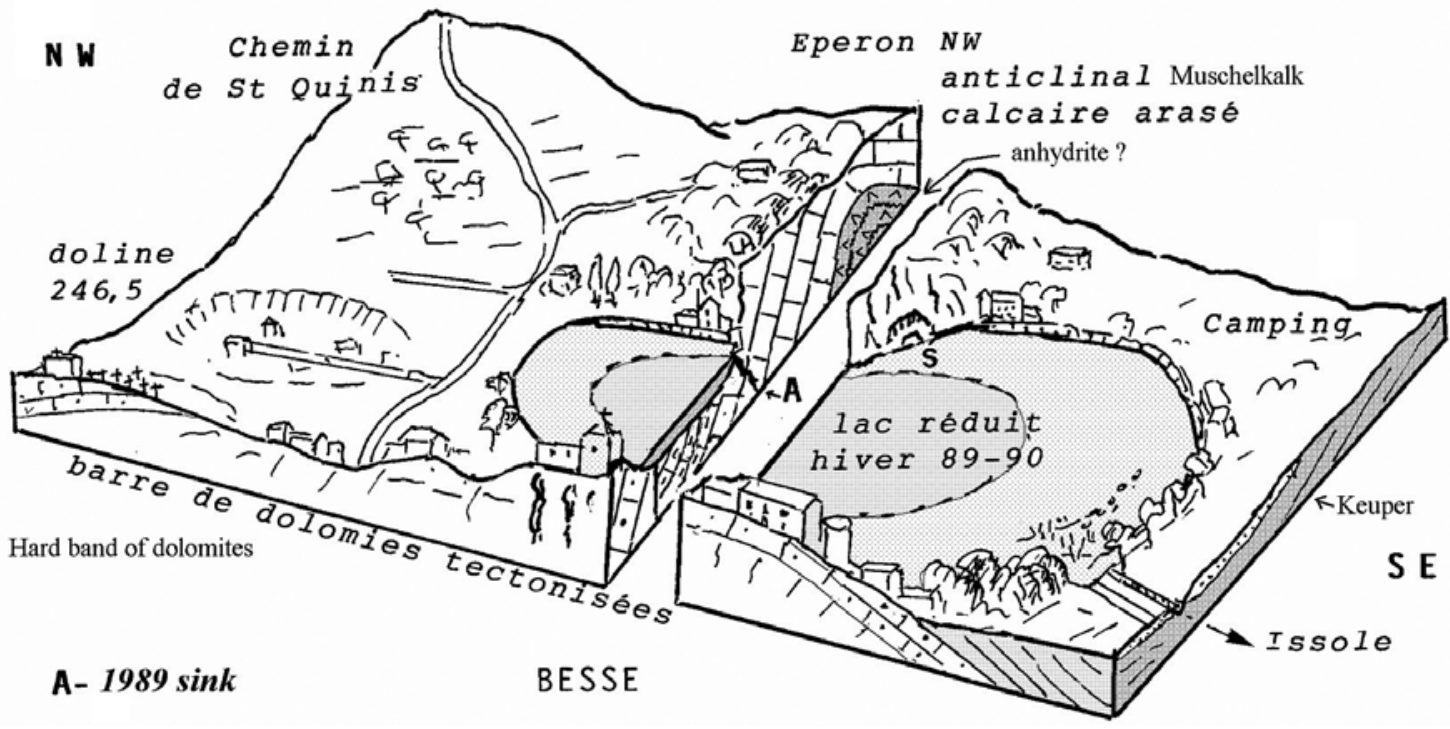

Fig. 2: Sketch of the lake of Besse, in its geological site.

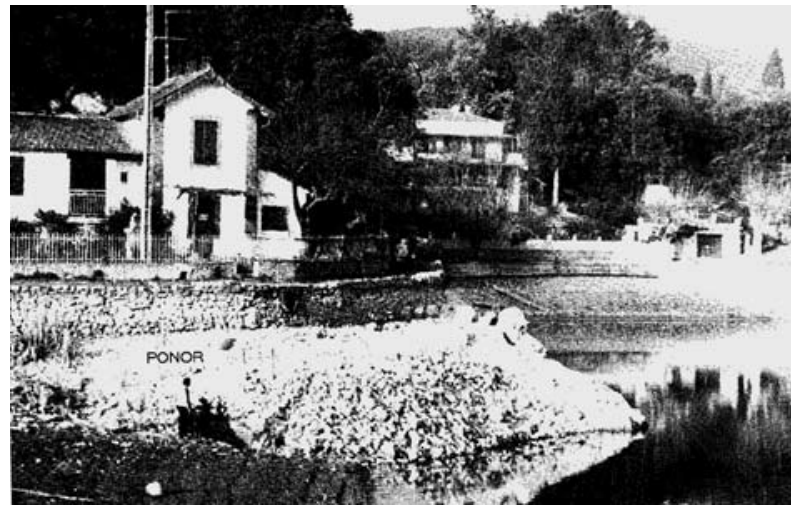

Fig. 3: Partly draining of the Lake of Besse in December 1989, by cleared pipe in the Muschelkalk spur. Lakes 1)

Tourrettes in eastern Var Department. This phenomenon in lake of Besse is in relation with the drastic subsidence of the water-table, near $20 \mathrm{~m}$. Two factors are added:

- the effect of several consecutive dry years;

- the effect of the over-working of the alluvial groundwater in the Issole valley by numerous well-borings, because the two aquifers are partly in connection.

Some improvment are worked in 1990, financed by Var Department:

- tightness of the critic area, by a cover of clay compacting;

- refitting of the canal from Issole river.

For this improvment, the lake level is restored; unfortunately a new falling occurs for some years, in relation with new dry climatic period.

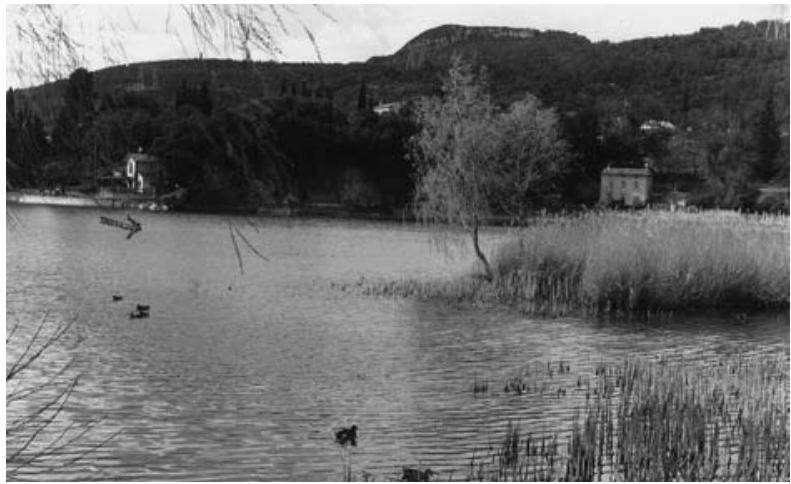

Photo 6: The lake of Besse-sur-Issole (Central Var Department) in 2005. View towards the Muschelkalk spur. Arrow marks the place of the 1989 sink.

Furthermore, in the decreased lake, the water become sligtly anoxic. These conditions cause some environmental problemes in the town of Besse, because the circumference of the water plan is shady recreation area, very important at the time of summer days for the citizens and tourists of next camping.

The decay of the Lago di Pergusa (near Enna, in Central Sicily).

That larger lake $\left(1.83 \mathrm{~km}^{2}\right)$, without outlet, is located in a wide oval karstic basin, from subsidence origin, in pliocene marls, upper gypsums of the gessoso-solfifera formation of Messinian (upper Miocene) (fig. 4). Numerous karstic phenomenons are recognized in this formation (FORTI \& SAURO, 1996). The flowing on the surroundly sides (catchment area of $6 \mathrm{~km}^{2}$ ), and the ground- 


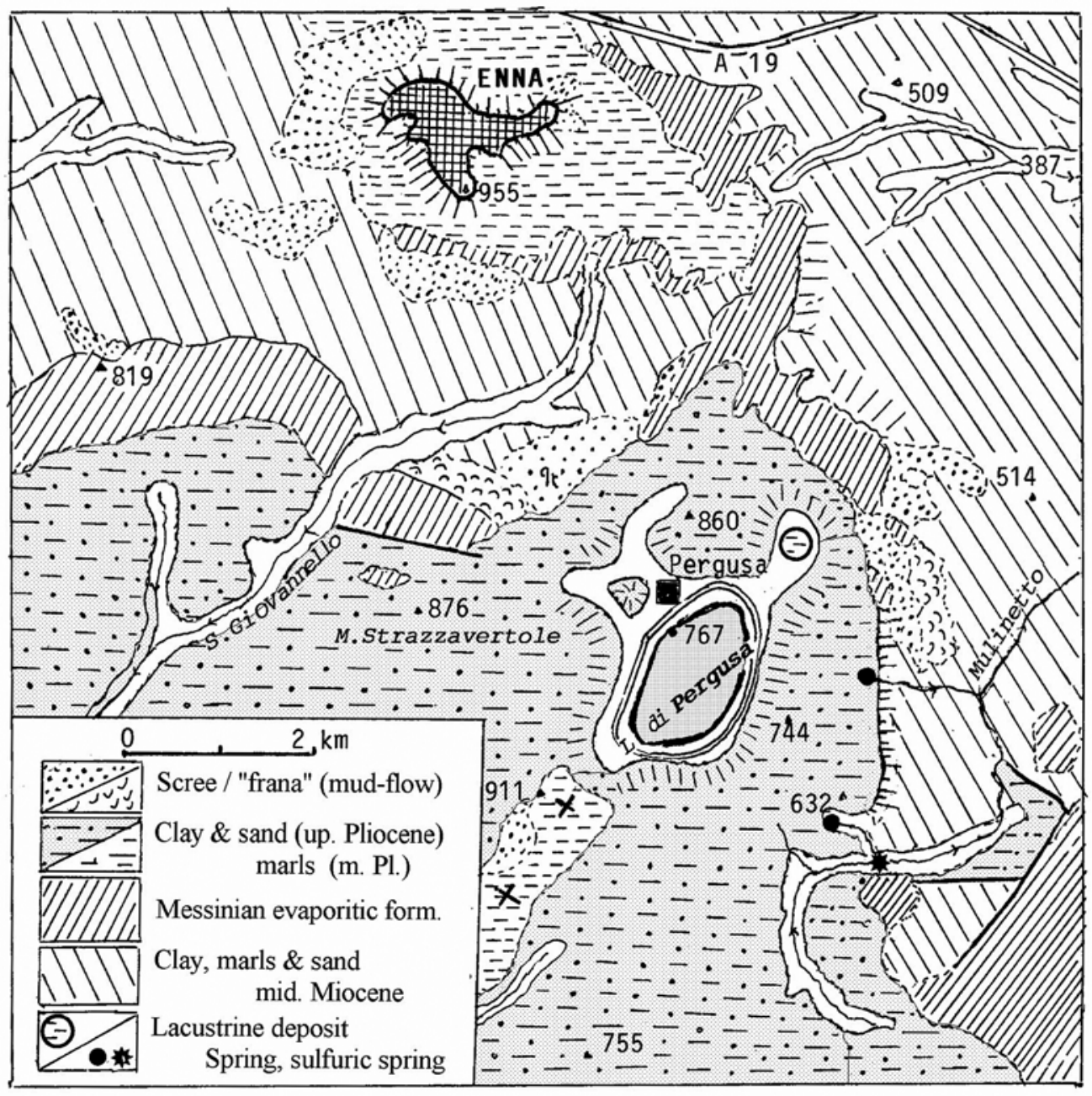

Fig. 4: The Lago di Pergusa, in its environment. Geology from the Carta Geologica d'Italia, 1/100 000, CALTANISSETTA, II Ediz., 1955 water of multilayered aquifer maintain the level. But its surface is reduced by the sedimentation, with silts from the weathering in Pliocene marls, and aquatic vegetation growth; moreover its level tend to subside (Tabl. 2).

Tab. 2: Decay of the Lago di Pergusa, from D’AMORE, 1983.

\begin{tabular}{|l|c|c|}
\hline \multicolumn{1}{|c|}{ Dimensions } & 1896 & 1977 \\
\hline Perimeter & $5.5 \mathrm{~km}$ & $4.3 \mathrm{~km}$ \\
Surface & $1.83 \mathrm{~km}^{2}$ & $1.35 \mathrm{~km}^{2}$ \\
Maximum depth & $4.6 \mathrm{~m}$ & $2.4 \mathrm{~m}$ \\
Middle depth & $2 \mathrm{~m}$ & $1.8 \mathrm{~m}$ \\
Volume & $5.8 \times 10^{6} \mathrm{~m}^{3}$ & $2.6 \times 10^{6} \mathrm{~m}^{3}$ \\
\hline
\end{tabular}

Unfortunately, the site has been altered in the sixties at the time of the development programme of Mezzogiorno: an autodrom has encircled the lake! The growth of the Pergusa village, with hotels and campings, has increased the water polllution in summer, and the eutrophication with the proliferation of the green algae (Charophyceae). For to cure to the site deterioration, the Consorzio di Bonifica di Borgo Cascino di Enna supply the lake from the regional hydrosystem and the site has been classified as «Green Zone».

The Estany de Banyoles (Bañolas), the large lake of Catalonia in urban area.

The large lake $\left(\sim 2 \mathrm{~km}^{2}\right)$ of Banyoles is situated in the NE of Barcelona, at the active tectonic boundary between the hills of Garrotxa and the subsiding basin of the Ampurdan (fig. 5). The lacustrine complex depression is located in the blue marls over gypsum and limestone formations of the Eocene. The confined artesian aquifer of these limestones, supplied by a large catchment in the north-western hills, concurs to gypsum dissolution.

The lake has a double origin:

- the coalescence of some funnels and subsidence depressions; 


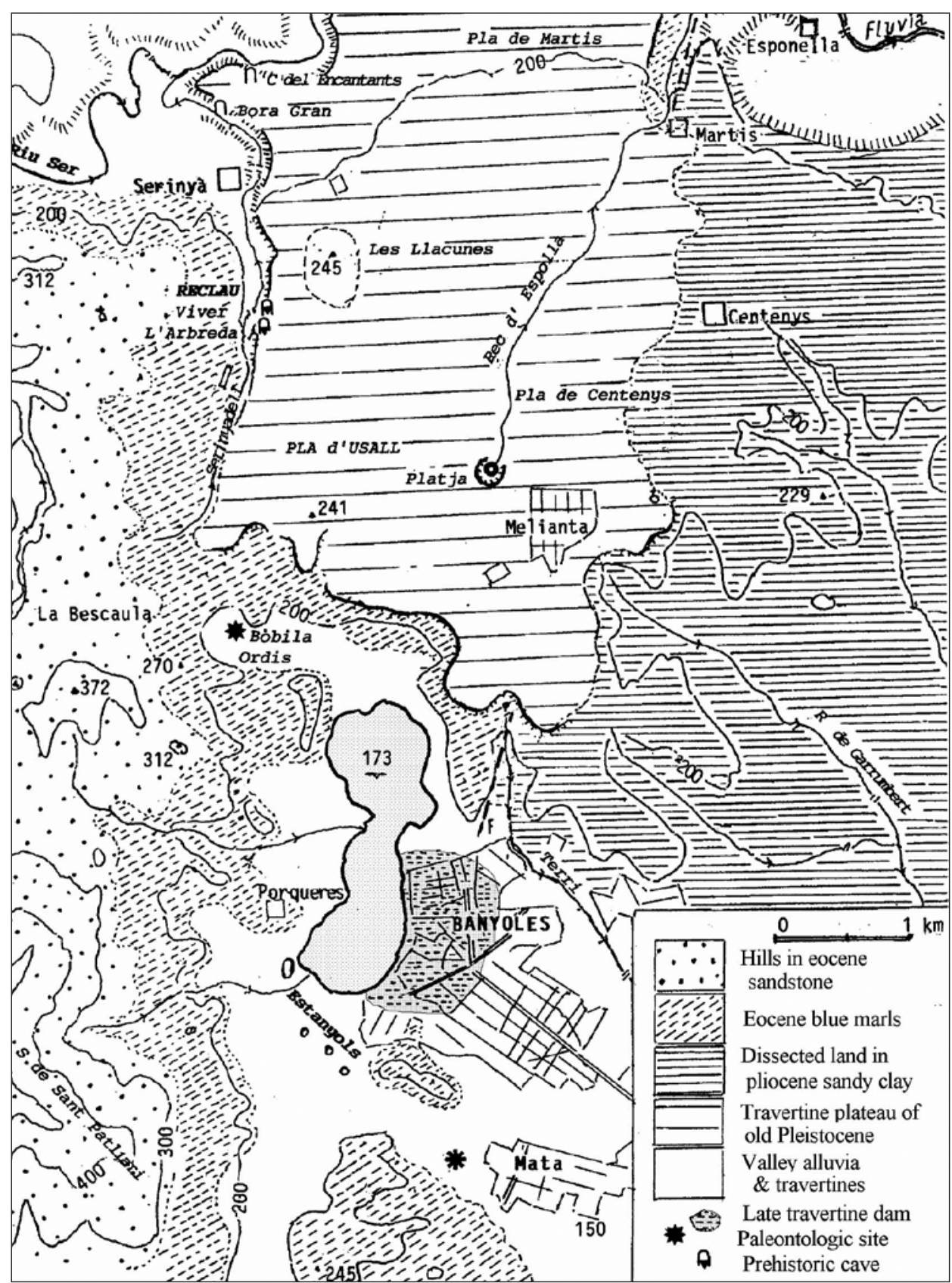

Fig. 5: The geomorphological situation of the lake of Banyoles.
- the water-level control by a travertine dam, builded on the Riu Terri outlet.

Round the lake, eight ponds (estanyols), of which one from a recent collapse in 1978 near Porqueres, show the enlargement by the solution and subsidence processes. In the lake bottom, several deep funnels (Cap de Bou $-130 \mathrm{~m}$ ) play as artesian springs (fig. 6). In funnels, sulphate muds are in suspension (SANZ, 1985).

The travertine dam has been builded on the waterfalls at the outlet of the lake to Riu Terri, with waters of high carbonate-sulphate mineralization and by the action of the incrusting algae (Cyanophyceae) (JULIA BRU-
GUES, 1980). A part of the town of Banyoles is builded on the travertines and several levels of travertine formations are extended in the Terri valley, with paleontological and archeological sites; but the oldest and highest accumulation is the Pla d'Usall in the north. In this plateau, the Platja spring, more $40 \mathrm{~m}$ above the lake-level, proves again the power of the artesian hydrosystem.

The Estany of Banyoles constitutes an noteworthy ecological site with its ichtyologic fauna (abundance of carps), but also important recreation area for all water sports. Clearly that activity, and the urbanization of the area round the lake are pollutant sources. 


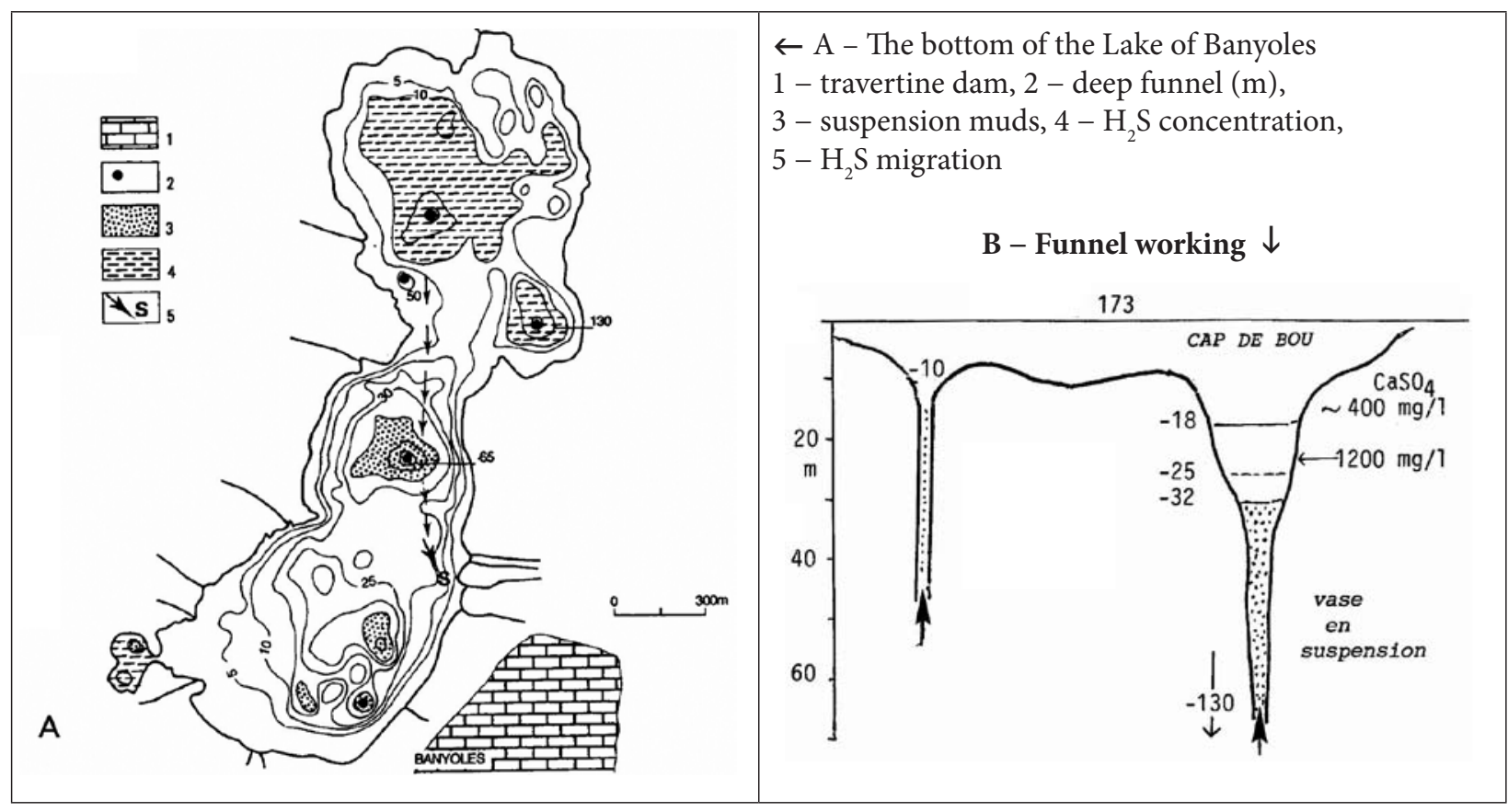

Fig. 6: The bottom of the Lake of Banyoles (from SANZ,1985).

\section{CONCLUSION}

The three lakes of Besse, Pergusa, and Banyoles show the most representative examples of environmental hazards and problems. As all phenomenons in gypsum karsts, their evolution depends on the active dissolution, and specific hydrogeological conditions. On account that produces high sensivity to anthropogenic changes, particularly with. the extent of urbanization atreas. 


\section{REFERENCES}

Abella, C. i Amettler 1986: L'Estany de Banyoles con a unitat ecologica; «1 Jornades sobre l'Estany de Banyoles (1984)», Diputació de Girona, p. 27-32.

Alagöz, C.A., 1967: Jips karst Olaylari ... - Les phénomènes karstiques du gypse aux environs et à l'est de Sivas; Ankara Universitesi Pasimevi, 126 p. + cartes h.t.

Andreichuk, V. \& Klimchouk, A., 2002: Karst breakdown mechanisms from observations in the gypsum caves of the western Ukraine: implications for subsidence hazard assessement; Int. J. Speleol. 31 (1/4) p. 5588.

Bulgäreanu, V.A.C., 1997: Solution lakes in gypsum evaporites: Lake Invârtita (Nucşoara) Romania; Internat. J. of Salt Karst Research, 6, p. 55-65.

D’Amore, G., 1983: Il problema della conservazione e della utilizzazione del lago di Pergusa; Atti del Convegno: La protezione dei laghi e delle zone umide in Italia, Memorie Soc. Geogr. Italiana, XXXVIII**, p. 405-411.

El Khalki, Y. \& Akdim, B., 2001: Les dolines d'effondrement et les dolines-lacs des Causses du SW du Moyen Atlas (Maroc); Karstologia 38, p. 19-24.

Forti, P. \& Sauro, U., 1996: The Gypsum karst in Italy; «Gypsum karst of the World», Internat. J. Speleology, Roma, 25 (3-4), p; 339-250.

Julia Brugues, R., 1980: La conca lacustre de Banyoles Besalu; Centro d'Estudios Comarcals de Banyoles, $188 \mathrm{p}$.
Klimchouk, A., 1996: The typology of gypsum karst; «Gypsum karst», Int. J. Speleol, 4, chap. 1-4, p. 4960

Klimchouk, A., 2002: Subsidence Hazards in different Types of Karst: Evolutionary and speleogenetic Approach.; Int. J. Speleol., 31 (1/4), p. 5-18

Martin, J. 1981: Le Moyen Atlas central, étude géomorphologique. (Thèse Paris VII, 1977); Notes et Mémoires du Service géol. du Maroc, 288 et 288 bis, 445 p., 110 fig., 32 ph. 5 cartes.

Nicod, J., 1988: Le Beaufortin oriental; Revue de Géog. Alpine, Grenoble, LXXVI (2), p. 121-146.

Nicod, J., 1993; Karsts des gypses, Morphologie, hydrologie, environnement; Karstologia $n^{\circ}$ 21, p. 21-30.

Nicod, J., 1999: Phénomènes karstiques et mouvements de terrain récents dans le Dépt. du Var; Risques naturels (Avignon 1995), CTHS, Paris, p. 115-130.

Priesnitz, K., 1969: Der Nixseebecken, ein Polje im Gipskarst des südwestlichen Harzvorland; Jb. Karst u. Höhlenkunde (München), H.9, XVI, p. 73-87.

Pulido-Bosch, A., 1989: Les gypses triasiques de Fuente Camacho: Réunion franco-espagnole sur les karsts d 'Andalousie, p. 65-82.

Sanz, M., 1985: Estudi hidrogeologic de la Conca de Banyoles-Garrotxa, Centro d'Estudios Comarcals de Banyoles, $250 \mathrm{p}$.

Soriano, M.A., 1991: Characteristics of the alluvial dolines developed because of gypsum dissolution materials in the Central Ebro Basin (Spain); Z. Geomorph. N.F., Suppl. Bd. 85, p. 59-72. 